\title{
Analysis of Student's Mathematic Creative Thinking Difficulty after Interactive Multimedia Assisted Learning at 41 State Middle School in Medan
}

\author{
Dini Nurani, Edi Syahputra, Edy Surya \\ Postgraduate Mathematics Education study program, Medan State University, \\ Medan, North Sumatra, Indonesia
}

\begin{abstract}
This study aims to: (1) To analyze the level of students' mathematical creative thinking skills after learning Problem Based Learning assisted by interactive multimedia at 41 state middle school in Medan. (2) To analyze students' mathematical creative thinking difficulties after learning Problem Based Learning assisted by interactive multimedia at 41 state middle school in Medan. This type of research is qualitative. The subjects in this study were students 41 state middle school in Medan Class VIII as many as 20 students. The results showed: (1). The level of students' mathematical creative thinking ability on the material of a two-variable linear equation system in students with medium and high abilities has the highest proportion, followed by students with low abilities (2). Mathematical creative thinking skills in problem-based learning are generally found in elaboration indicators (3) The student's answer process in creative thinking in problem-based learning is very varied, in the high category it can be completed well.
\end{abstract}

Keywords: Creative thinking skills, Problem Based Learning, Interactive Multimedia.

DOI: $10.7176 / \mathrm{JEP} / 13-3-05$

Publication date: January $31^{\text {st }} 2022$

\section{Introduction}

The importance of mathematics is one of the subjects that is a major concern, but mathematics is still a difficult subject for students. Based on Mufidah's research (2019) stating that students' mathematics learning outcomes are low, there are still many students who get scores below the minimum completeness criteria based on interviews or initial observations with mathematics teachers at SMP Negeri 1 Pogalan because students have difficulty solving math problems. This can be seen when the teaching and learning process takes place students are less active in providing feedback to the teacher, only very few are able to answer the teacher's questions. So this has an impact on the low learning outcomes of mathematics achieved by students. The factors that cause high and low mathematics learning outcomes include the level of students' creative thinking and difficulty in solving problems.

According to Soejono (1994: 254) indicators of difficulty in solving math problems include: difficulty in understanding concepts, arithmetic operations, and difficulties in understanding principles. Factors causing difficulties in solving problems According to Soedjadi (2011: 1), the difficulties made by students can be classified into various forms of errors as follows. (1) Procedural errors in using algorithms (work procedures), for example errors in performing arithmetic operations. (2) Errors in organizing data, for example writing errors in what is known, what is being asked of a question. Error sorting, grouping and presenting data. (3) Errors in the use of symbols, tables, and graphics containing information. (4) Errors in performing mathematical manipulations. For example, errors in using or applying trait rules in solving problems. (5) Errors in drawing conclusions. For example, errors in writing conclusions from the problems they have been working on. As educators who are responsive, they must have a responsive attitude when students experience difficulties in learning activities. As revealed by Novita (2016) which states that the actions of educators in overcoming the difficulties of students both in studying or understanding the material being studied are a form of professional development of educators.

The results of a survey conducted by the International Program for International Students Assessment (PISA) in 2012 placed Indonesia in 64th place out of 65 countries. Indonesia got a score of 375 in mathematics, while China was far different from occupying the first position with a score of 630 . This shows that competition participants from Indonesia are still weak in solving problems related to higher-order thinking skills, one of which is the ability to think creatively. Thus, it can be said that the creative thinking ability of competition participants from Indonesia is still in the low category. Therefore, efforts are needed to continuously improve and enhance students' creative thinking skills in learning mathematics.

Based on the results of observations and interviews conducted at SMP Negeri 41 Medan Medan that daily mathematics learning activities do not motivate students to be directly involved in forming knowledge related to students' mathematical creative thinking skills. Teachers still emphasize teacher-centered learning so that students are less active resulting in low students' mathematical creative thinking skills. The students' mathematical creative thinking ability can be seen from the students' answers to the creative thinking ability test which is still low. Students have not been able to develop mathematical creative thinking through the learning provided by the teacher. 
Whereas learning is aimed at developing the potential of students to have the ability to live as creative and innovative individuals who have the ability to seek, process, construct, and use knowledge.

The inability of students to solve problems related to mathematical creative thinking as stated above, as an indicator of problems faced by teachers in the field. The low achievement of students' mathematics is influenced by errors in learning.

One of the efforts that can develop students' creative thinking skills is to use learning methods using the Problem based learning model. Problem Based Learning is learning that uses real-world problems as a context for students to learn creative thinking and problem solving skills, as well as to gain knowledge and skills. concepts that are the essence of the subject matter.

In line with Surya's opinion, Dermawan and Syahputra (2017) stated "By applying this model, it is hoped that the learning that takes place can be more meaningful and give a strong impression on students, and of course can improve mathematical creative thinking skills.

\section{Methods}

Types of research

This type of research is qualitative. Based on the descriptive qualitative approach in this study, all facts, both written and oral from human data sources that have been observed and other related documents, are described as they are and then reviewed as briefly as possible to answer the problem.

\section{Research subject}

The subjects in this study were students at 41 state middle school in Medan Class VIII as many as 20 students.

\section{Research Instruments}

The instruments include tests of mathematical creative thinking skills and interview guidelines.

\section{a. Students' Mathematical Creative Thinking Ability Test}

The type of test that is prepared refers to the competence to be achieved by benchmarking the assessment. The number of questions used in this test instrument which is used as a measuring tool is 4 (four) items in the form of essays.

Table 1. Indicators (Grid) of Mathematical Creative Thinking Ability

\begin{tabular}{|c|l|c|}
\hline Aspect & \multicolumn{1}{|c|}{ Indicator } & Question Number \\
\hline Fluency & Students are able to provide many ideas smoothly in solving problems & $1,2,3,4$ \\
\hline Flexibility & Students are able to solve problems from different perspectives & $1,2,3,4$ \\
\hline Originality & Students are able to solve problems in their own way & $1,2,3,4$ \\
\hline Elaboration & Students are able to develop or detail a situation in detail & $1,2,3,4$ \\
\hline
\end{tabular}

\section{b. Interview guidelines}

In accordance with the purpose of this study, the data that became the core to be analyzed were the data from the students' mathematical creative thinking ability test results and the data from student interviews. The interview referred to in this study is an in-depth interview conducted to research subjects by teachers who carry out Problem Based Learning learning to obtain in-depth data about students' creative thinking difficulties in solving problems using the Problem Based Learning learning model.

\section{Data collection technique}

The data collection methods needed in this study were tests of students' mathematical creative thinking skills, interviews with students and teachers, observations or observations by observers and documentation in the form of photos during the learning process.

\section{Data analysis}

Data analysis in this study uses qualitative data analysis where data analysis is carried out after giving a learning action. According to Bogdan (in Trianto, 2011: 285) argues that qualitative data analysis is the process of systematically searching and compiling data obtained from interviews, field notes, and other materials so that they are easy to understand so that they can be informed to others.

Activities in data analysis using the Miles and Huberman model, namely data reduction, data display, and conclusion drawing/verification data. The two methods also complement each other but the Spradley method starts from the broad, then focuses, and expands again (Sugiyono, 2009:347). This means that the research uses the Miles and Huberman method where the three steps of data analysis are also present in all stages of the qualitative research process. 
Result

Description of Students' Creative Thinking Ability

In table 2. below, the percentage of test results for the ability to think creatively based on high, medium, and low categories will be presented after being given learning using a problem based learning model which can be seen in table 2. below:

Table 2. Students' Mathematical Creative Thinking Ability Level Test

\begin{tabular}{|c|c|c|c|c|}
\hline Number & Value Interval & The number of students & Percentage & Rating Category \\
\hline 1 & $85 \leq$ Value $\leq 100$ & 7 & $35 \%$ & High \\
\hline 2 & $65 \leq$ Value $<85$ & 7 & $35 \%$ & Medium \\
\hline 3 & $0 \leq$ Value $<65$ & 6 & $30 \%$ & Low \\
\hline & Average & \multicolumn{3}{|c|}{73,43} \\
\hline
\end{tabular}

Based on the results of the 20 students' creative thinking ability test, the students' mathematical creative thinking ability levels were spread across three criteria, namely low, medium, and high. Based on table 2., it can be seen that the level of students' mathematical creative thinking skills with the problem based learning model. There are 7 students with high ability (35\%), medium ability students 7 people (35\%), and students with low ability as many as 6 people $(30 \%)$.

\section{Analysis of Difficulties in Solving Students' Mathematical Creative Thinking Ability Problems in Mathematics}

a. Analysis of Difficulties in Solving Problems with High Ability Mathematical Creative Thinking Skills

Based on the test results obtained from students with high abilities, the difficulties found in solving these problems are in principle difficulties. This can be seen from the mathematical work that does not understand how to solve the problem. This shows that the student has no difficulty in facts, principles and operations. For creative thinking skills, students are required to be able to solve problems in many different ways. In the high category ability, students have been able to solve problems in many different ways.

This shows that students' ability to solve mathematical difficulties is still relatively high. Students are able to develop mathematical creative thinking through the learning provided by the teacher. Whereas learning is aimed at developing the potential of students to have the ability to live as creative and innovative individuals who have the ability to seek, process, construct, and use knowledge.

b. Analysis of Difficulties in Solving Problems with Students' Mathematical Creative Thinking Ability Medium Ability

Based on the test results obtained from students with moderate abilities, the difficulties found in solving these problems are in concept difficulties. This can be seen from the work of mathematics that does not understand how to work and solve problems in many ways. For creative thinking skills, students are required to be able to solve problems in many different ways.

This shows that the ability of students in solving mathematical difficulties of students is still relatively low. Students have not been able to develop mathematical creative thinking through the learning provided by the teacher. Whereas learning is aimed at developing the potential of students to have the ability to live as creative and innovative individuals who have the ability to seek, process, construct, and use knowledge.

c. Analysis of Difficulty in Solving Problems in Creative Thinking Mathematical Ability of Low Ability Students

Based on the results of student tests on low abilities, it was found that the difficulties contained in solving these questions were found in all indicators of difficulty. Based on the answer sheets of low ability students, then an analysis of students' mathematical difficulties was carried out based on indicators of mathematical difficulty. It can be seen that students still do not meet the indicators of difficulty in facts, concepts, principles, and operations. This shows that students' mathematical difficulties are still relatively low. Students have not been able to develop mathematical creative thinking through the learning provided by the teacher. Whereas learning is aimed at developing the potential of students to have the ability to live as creative and innovative individuals who have the ability to seek, process, construct, and use knowledge.

\section{Discussion}

In the learning process which was carried out for three meetings in class VIII at SMP Negeri 41 Medan that the level of difficulty of students in students' creative thinking skills was reduced after the implementation of the Problem Based Learning learning model compared to previous learning which still used conventional learning in the form of lectures or just explaining theory.

From the results of the study found various difficulties experienced by students in answering questions. The difficulty of students from the category of low creative thinking abilities is that students almost have difficulty in solving all the questions given. The indicator of creative thinking ability that meets only fluency. While on the 
indicator of difficulty, students have difficulty in solving problems, namely difficulties on indicators of facts, concepts, principles and operations. Then the difficulty of students from the category of moderate creative thinking abilities, namely the indicators of originality and elaboration. In addition to the ability to think creatively in the moderate category, it can be seen that students still do not meet the indicators of difficulty in concepts, principles, and operations. This shows that students' mathematical difficulties are still relatively low. Students have not been able to develop mathematical creative thinking through the learning provided by the teacher. And the difficulty of students from the category of high creative thinking ability is only on the elaboration indicator. In addition to the ability to think creatively in the high category, it can be seen that students have almost no difficulties in the indicators of difficulty in facts, concepts, principles, and operations. This shows that students' ability to solve mathematical difficulties is still relatively high. Students are able to develop mathematical creative thinking through the learning provided by the teacher.

Savery (2006), University of South Carolina entitled Overview of Problem Based Learning said that learning with the Problem Based Learning (PBL) model is a learning that has been used successfully for 30 years and continues to receive acceptance in various disciplines. This overview provides a brief history, followed by a discussion of the similarities and differences between PBL and other experiential approaches to teaching, and identifies some of the challenges.

Problem Based Learning learning model is very helpful for students in improving students' creative thinking skills. Rangkuti, et al (2014) Medan State University with the title "Improving Conceptual Understanding and Mathematical Creative Thinking Ability of Vocational High School Students through Problem-Based Learning" also suggested that problem-based learning can be used as an alternative learning model used in schools primarily to achieve higher-level thinking competence high.

\section{Conclusion}

1. The level of students' mathematical creative thinking skills on the material of a two-variable linear equation system in students with medium and high abilities has the highest proportion, followed by students with low abilities.

2. Difficulty in mathematical creative thinking skills in problem-based learning, as follows:

a. In the high category, students did not experience significant difficulties.

b. In the medium category, students have difficulty understanding concepts so that students experience confusion when solving problems; and students also have difficulty in operating the equation.

c. In the low category, students have difficulty in all indicators of critical thinking skills. Students are not able to use the solution method so they are unable to solve the problem.

3. The process of students' answers in creative thinking in problem-based learning, as follows:

a. In the high category, students have been able to solve problems on each indicator well. In the elaboration indicator there are students who do not finish well.

b. In the medium category, students have been able to solve problems on indicators of fluency, flexibility, and originality. On the originality indicator, there are students who do not finish well.

c. In the low category, students have not been able to solve problems in almost all indicators.

\section{References}

Adyani, Novita, dkk. 2016. "Peningkatan Kemampuan Menulis Teks Eksplanasi dengan Menggunakan Media Audiovisual pada Siswa Sekolah Menengah Pertama. BASASTRA Jurnal Penelitian Bahasa, Sastra Indonesia dan Pengajarannya”. 4 (2): 161. Mufidah, Hanik. 2019. Analisis kesulitan siswa dalam menyelesaian soal matematika ditinjau dari tingkat berpikir kreatif. JP2M (Jurnal Pendidikan dan Pembelajaran Matematika)

Grzeszczyk, K. B. (2016). Using Multimedia in The English Language Classroom. Journal World Scientific News, 43(3), 104-157.

Lufri.2007.Strategi Pembelajaran Biologi Teori, Praktek dan Penelitian.UNP. Press.Padang.

Misnasanti, Utami, R. W., \& Suwanto, F. R. (2017). Problem Based Learning to Improve Proportional Reasoning of Students in Mathematics Learning. AIP Conference Proceedings, 1868. https://doi.org/10.1063/1.4995129

Rangkuti, Sahat Saragih \& Hasratuddin. 2014. Prosising, Peningkatan Kemampuan Pemahaman Konsep dan Pemecahan Masalah Matematis Siswa SMK melalui Pembelajaran Berbasis Masalah. Jurnal PARADIKMA, Vol. 7 Nomor 3, Hal. 1-10.

Savery, J. R. 2006. Overview of Problem-based Learning: Definitions and Distinctions. Interdisciplinary Journal of Problem-Based Learning, Volume.1

Soedjadi. 2011. Kiat Pendidikan matematika di Indonesia. Jakarta: Dirjen Dikti.

Soejono. 1994, Diagnosis Kesulitan Belajar dan Pengajaran Remidial Matematika. Jakarta: Depdikbud Dirjen Dikti PPLPTK.

Sugiyono. 2009. Metodologi Penelitian Pendidikan. Bandung: ALFABETA.

Surya, Edy., Dermawan, D. A., \& Syahputra, Edi. 2017. The Efforts To Improving The Creative Thinking Ability 
Through Problem-Based Learning Of Junior High School Students. International Journal of Novel Research in Education and Learning Vol. 4, Issue 2, pp: 29-40.

Trianto. 2011. Mendesain Model-Model Pembelajaran Inovatif-Progresif. Jakarta: Kencana Prenada Media Group. 